\title{
CAN AN ETHICAL PERSON BE AN ETHICAL PROSECUTOR? A SOCIAL COGNITIVE APPROACH TO SYSTEMIC REFORM
}

\author{
Lawton P. Cummings*
}

INTRODUCTION

Several recent cases highlight the need for a deeper understanding of intentional prosecutorial misconduct. ${ }^{1}$ In one high profile example,

* Visiting Associate Professor of Law, The George Washington University Law School. I would like to thank Professors Ellen Yaroshefsky and Bruce Green for providing me the opportunity to participate in the Symposium on prosecutors' disclosure obligations that led to this publication. I would also like to express my gratitude to Professors Robert W. Tuttle and Tom Morgan for valuable comments and insights on drafts of this Article, Elta Lea Johnston for inspiring me with social science articles, and Jacqueline R. Ingber for her excellent research assistance. Finally, my utmost gratitude to my husband, Craig, and my children, Addison and Cooper, whose support make all of my endeavors possible.

1 The term "prosecutorial misconduct" encompasses a broad range of behavior. It includes bringing charges that are not supported by probable cause. See MODEL RULES OF PROF'L CONDUCt R. 3.8(a) (2003); see also STANDARds FOR CRIMINAL JUSTICE: Prosecution FUNCTION \& DEF. FUNCTION § 3-3.9(a) (3d ed. 1993) ("A prosecutor should not institute, or cause to be instituted, or to permit the continued pendency of criminal charges when the prosecutor knows that the charges are not supported by probable cause."). The term also covers introducing false evidence, witness tampering, and concealing exculpatory evidence from the defense. See Brady v. Maryland, 373 U.S. 83, 87 (1963) ("[T] he suppression by the prosecution of evidence favorable to an accused upon request violates due process where the evidence is material either to guilt or to punishment, irrespective of the good faith or bad faith of the prosecution."); see also United States v. Bagley, 473 U.S. 667, 682 (1985) (announcing a materiality standard for Brady material that applies uniformly, whether the defendant makes a request or not, stating that " $[\mathrm{t}] \mathrm{h}$ e evidence is material only if there is a reasonable probability that, had the evidence been disclosed to the defense, the result of the proceeding would have been different. A 'reasonable probability' is a probability sufficient to undermine confidence in the outcome."); Ken Armstrong \& Maurice Possley, The Verdict: Dishonor, Chicago Tribune, Jan. 10, 1999, at C1 (considering 381 cases where homicide convictions were dismissed due to prosecutors who concealed exonerating evidence or presented false evidence); Innocence Project, Government Misconduct, http://www.innocenceproject.org/understand/GovernmentMisconduct.php (last visited June 25, 2010) (noting that prosecutorial misconduct tainted thirtythree of seventy-four exonerations resulting from DNA evidence; more than a third of the overturned convictions involved suppression of exculpatory evidence).

While the Bagley materiality standard governs the prosecutor's constitutional duty to disclose exculpatory evidence and serves as the standard for post-trial remedy for prosecutorial misconduct, the ethics rules require prosecutors to disclose to the defense any evidence that "tends to negate the guilt of the accused or mitigates the offense," or mitigates the defendant's sentence. MODEL RULES OF PROF'L CONDUCT R. 3.8(d) (2003); see also STANDARDS FOR 
Judge Cormac Carney recently dismissed felony charges against former Broadcom executives William Ruehle and Henry T. Nicholas III, citing a string of prosecutorial misconduct that included intimidating witnesses, entering into invalid plea agreements, and wrongfully withholding material helpful to the defense. ${ }^{2}$ And who could forget Mike Nifong, the now disbarred former District Attorney who engaged in extensive willful prosecutorial misconduct in his prosecution of the Duke University lacrosse players, most notably concealing exculpating DNA evidence from the defendants. ${ }^{3}$

The most striking example in this recent string of cases involves that of Senator Theodore "Ted" Stevens, where the prosecutors who engaged in the willful misconduct that eventually came to light (including witness tampering and wrongful concealment of exculpatory documents $)^{4}$ were members of an elite group of prosecutors who were

CRIMINAl Justice: Prosecution FunCTION \& DeF. FunCTION § 3-3.11(a) (3d ed. 1993); Kyles, 514 U.S. at 437 ("[T] the ABA Standards for Criminal Justice, which call generally for prosecutorial disclosures of any evidence tending to exculpate or mitigate."). Additionally, Rule 3.8 requires prosecutors to make reasonable efforts to ensure that an accused has been informed of his or her rights and may not attempt to procure a waiver of any important pretrial rights from a person who is not represented by counsel, to take steps to remedy a conviction if she learns that a conviction was wrongfully obtained, and to refrain from making extrajudicial statements that will heighten the public's contempt for the accused. MODEL RULES OF PROF'L CONDUCT R. 3.8(b)-(c), (f) (2006). For a description of many of the forms of prosecutorial misconduct, see ANGELA J. DAVIS, ARBITRARY JUSTICE: THE POWER OF THE AMERICAN PROSECUTOR 125 (Oxford Univ. Press 2007).

2 See Stuart Pfeifer, New Court Victory for Broadcom Co-Founder Henry Nicholas as Drug Charges Are Dropped, L.A. TimES, Jan. 29, 2010, at B1.

3 See Shaila Dewan, Duke Prosecutor Is Jailed; Students Seek Settlement, N.Y. TIMES, Sept. 8, 2007, at A8. Additionally, the advent of DNA evidence and its use by groups such as the Innocence Project have led to the exoneration of numerous wrongfully convicted defendants, many of whom were convicted in part due to wrongful prosecutorial conduct. See Innocence Project, supra note 1; John Farmer, Prosecutors Gone Wild, N.Y. TIMES, Apr. 3, 2009, at A29 (discussing several high-profile prosecutorial misconduct cases, including that of Shih-Wei Su, to whom New York City paid $\$ 3.5$ million to compensate him for the nearly thirteen years that he wrongfully spent in prison due to the prosecution's knowing eliciting of false testimony from a key witness).

4 On July 29, 2008, prosecutors with the Public Integrity Section of the Department of Justice (DOJ) secured an indictment from a federal grand jury in the District of Columbia against then-Senator Theodore "Ted" Stevens, accusing him of making false statements on his Senate financial disclosure forms in order to hide $\$ 250,000$ in gifts from oil contractors in his home state of Alaska. See Indictment, United States v. Stevens, No. 08-CR-00231, 2008 WL 2894791 (D.D.C. July 29, 2009) (charging Ted Stevens with violating 18 U. S. C. $§ 1001$ (a)(1)-(2), (c)(1)(2)). Three months later, a jury convicted then Senator Stevens on seven felony counts. See Brent Kendall, Stevens Convicted on All Charges, WALl ST. J., Oct. 28, 2008, at A3. Eight days later, Ted Stevens, the longest-serving Republican in the history of the United States Senate, narrowly lost his bid for re-election. See Paul Kane, Sen. Ted Stevens Loses Battle for Alaska Senate Seat, WASH. POST, Nov. 19, 2008, at A1. However, rather than providing a banner of achievement for the elite Public Integrity Section, the Stevens case became a symbol of ethical violations within the very government office charged with prosecuting public corruption. See Neil A. Lewis \& David Johnston, Dismayed Lawyers Lay Out Reasons for Collapse of the Stevens Conviction, N.Y. TIMES, Apr. 7, 2009, at A20. The Stevens prosecutors' misconduct was pervasive. During the five-week trial, Federal District Court Judge Emmet Sullivan repeatedly 
themselves charged with ferreting out public corruption - the Public Integrity Section of the Department of Justice. The challenging questions raised by the misconduct in such cases are: What leads otherwise ethical prosecutors to engage in misconduct, and how can such misconduct be prevented in the future?

Social cognitive theory, which considers both cognitive and situational influences upon behavior, ${ }^{5}$ is a natural fit to analyze prosecutorial misconduct, and a growing literature of legal scholarship has used social cognitive theory as such a lens. ${ }^{6}$ However, such scholarship has focused on prosecutors' biased assimilation of evidence that can lead a prosecutor to unknowingly violate ethical duties. ${ }^{7}$ Such research has left intentional prosecutorial misconduct largely unexplored. This Article will begin to fill the gap in the current

scolded the prosecutors for making false representations to the court and for withholding exculpatory evidence from the defense. See Neil A. Lewis, Tables Turned on Prosecution in Stevens Case, N.Y. TIMES, Apr. 8, 2009, at A1. In March 2009, United States Attorney General Eric Holder moved to dismiss the charges against Senator Stevens, stating that lawyers reviewing the case discovered evidence that prosecutors improperly concealed evidence from the defense. See Motion of the United States to Set Aside the Verdict and Dismiss the Indictment with Prejudice, United States v. Stevens, No. 08-231 EGS, 2009 WL 83933 (D.D.C. Apr. 1, 2009); see also Neil A. Lewis, Justice Department Moves to Void Stevens Case, N.Y. TIMES, Apr. 2, 2009, at A1.

5 See, e.g., Albert Bandura, Social Foundations of Thought And Action: A SOCIAL COGNITIVE THEORY (1986).

6 See Dianne L. Martin, Lessons About Justice from the "Laboratory" of Wrongful Convictions: Tunnel Vision, the Construction of Guilt, and Informer Evidence, 70 UMKC L. REV. 847,848 (2002) (arguing that cognitive biases can lead to "tunnel vision" whereby prosecutors unconsciously "focus on a suspect, select and filter the evidence that will 'build a case' for conviction, while ignoring or suppressing evidence that points away from guilt"); see also Alafair S. Burke, Improving Prosecutorial Decision Making: Some Lessons of Cognitive Science, 47 WM. \& MARY L. REV. 1587 (2006) [hereinafter Burke, Improving Prosecutorial Decision Making] (examining cognitive biases that can affect prosecutorial decision-making and proposing reforms to mitigate such biases); Alafair S. Burke, Revisiting Prosecutorial Disclosure, 84 IND. L.J. 481, 481, 494 (2009) [hereinafter Burke, Revisiting Prosecutorial Disclosure] (proposing a "prophylactic open file rule to effectuate defendants' Brady rights" and arguing that current materiality standard under Brady "acts upon cognitive biases from which prosecutors, like all human decision makers, suffer").

7 Much of this literature focuses on the phenomenon referred to as "tunnel vision." See Martin, supra note 6, at 848; see also Susan Bandes, Loyalty to One's Convictions: The Prosecutor and Tunnel Vision, 49 How. L.J. 475 (2006). While Bandes briefly considers moral disengagement, she focuses instead on cognitive neuroscience and cognitive biases to examine prosecutors' "refusal to consider alternative theories or suspects during the initial investigation, or to accept the defendant's exoneration as evidence of wrongful conviction" due to "fierce loyalty to a particular version of events." Id . at 479; see also Burke, Improving Prosecutorial Decision Making, supra note 6; Burke, Revisiting Prosecutorial Disclosure, supra note 6, at 481, 494; Alafair S. Burke, Neutralizing Cognitive Bias: An Invitation to Prosecutors, 2 N.Y.U. J.L. \& LiBERTY 512 (2007) (same); Myrna Raeder, What Does Innocence Have to Do with It?: A Commentary on Wrongful Convictions and Rationality, 2003 MICH. ST. L. REV. 1315, 1327 (2003) (considering biases that lead to tunnel vision by prosecutors). Social cognitive research has also been used to explain prosecutors' disbelief of defendants' post-conviction evidence of innocence and prosecutors' inflated plea bargaining positions. See Alafair S. Burke, Prosecutorial Passion, Cognitive Bias, and Plea Bargaining, 91 MARQ. L. REV. 183 (2007). 
literature by employing Albert Bandura's moral disengagement theory as a lens through which to analyze intentional prosecutorial misconduct. This Article will also examine the factors present in the prosecutorial system that may support willful prosecutorial misconduct by encouraging moral disengagement in otherwise ethical prosecutors.

Part I of this Article provides a brief overview of Moral Disengagement Theory. Part II examines the moral disengagement mechanisms present in the prosecutorial system and concludes that certain key aspects of the prosecutorial system encourage otherwise good prosecutors to disengage their morality, which can lead to prosecutorial misconduct. Part III considers possible reforms to the prosecutorial system that could mitigate such moral disengagement.

\section{Moral Disengagement THEORY}

A discussion of moral reasoning and moral control pre-supposes that the decision-maker has an internalized code of ethics. In social cognitive theory, an individual's moral standards are constructed through the process of "socialization," whereby the society's standards are adopted "from information conveyed by direct tuition, evaluation of social reactions to one's conduct, and exposure to the self-evaluative standards modeled by others." 8 Through self-regulation, a person will engage in actions that conform to her personal conceptions of morality in order to gain self-respect and maintain self-worth. She will refrain from engaging in behavior that is contrary to her internal moral standards, so as to avoid self-condemnation. ${ }^{9}$ Social cognitive research has demonstrated that individual decision-makers are highly motivated to maintain moral self-image and avoid self-sanctions. ${ }^{10}$ As Mark

8 Albert Bandura et al., Mechanisms of Moral Disengagement in the Exercise of Moral Agency, 71 J. PERSONALITY \& SOC. PSYCHOL., 364, 364 (1996) (showing positive relationship between moral disengagement and aggression); see also Albert Bandura, Moral Disengagement in the Perpetration of Inhumanities, 3 PeRsonality \& Soc. PSYCHOL. ReV. 193 (1999) [hereinafter Bandura, Moral Disengagement in the Perpetration of Inhumanities] (documenting how moral disengagement mechanisms contribute to the perpetration of inhumanities).

9 Bandura, Moral Disengagement in the Perpetration of Inhumanities, supra note 8; see also Albert Bandura, Impeding Ecological Sustainability Through Selective Moral Disengagement, 2 InT. J. InNOVATION \& SuSTAInABle DeV. 8 (2007) [hereinafter Bandura, Impeding Ecological Sustainability] (examining the selective disengagement of moral self-sanctions as an impediment to reversing ecological degradation and explaining that people tend to "do things that give them satisfaction and a sense of self-worth, and refrain from behaving in ways that violate their moral standard because such conduct will bring self-condemnation").

10 Albert BANDURA, SElF-EFFiCACY: THE EXERCiSE OF CONTROL (1997); Albert Bandura, Social Cognitive Theory of Moral Thought and Action, in 1 HANDBOOK OF MORAL BEHAVIOR AND DeVELOPMENT 45 (Willam M. Kurtines \& Jacob L. Gewirtz eds., Erlbaum 1991); see also Albert Bandura, Social Cognitive Theory of Self-Regulation, 50 ORGANIZATIONAL BeHAV. \& Hum. Decision Processes 248 (1991) [hereinafter Bandura, Social Cognitive Theory of Self- 
Twain aptly stated, "A man cannot be comfortable without his own approval." 11

Social cognitive psychologists have shown that while "people can be motivated to engage in actions that violate moral principles," their "moral self-sanctions need to be short-circuited to enable individuals to act immorally" without the cost of self-sanctions. ${ }^{12}$ Albert Bandura and others have identified and studied the mechanisms that operate to disengage an individual's moral self-sanctions from injurious conduct and thereby "neutralize moral control."13 These moral disengagement mechanisms can be placed in three categories: reconstruing conduct as morally justified, obscuring personal agency, and blaming or dehumanizing victims. ${ }^{14}$ These mechanisms are particularly potent when present in combination and will "operate in concert rather than isolatedly at both the individual and social systems level."15

Empirical work has shown that an individual's "level of moral disengagement," i.e., the person's tendency to engage in moral disengagement mechanisms, is an accurate predictor of the person's level of aggression and anti-social behavior. ${ }^{16}$ Once a person's moral self-sanctions for harmful behavior toward a target are disengaged, moral control is weakened, and the actor may then engage in a process Bandura calls "gradualistic moral disengagement," 17 whereby "the level

Regulation].

11 MARK TwaIn, What Is Man?, in What Is MAN? AND OTHER ESSAYs 1, 17 (1917).

12 Jo-Ann Tsang, Moral Rationalization and the Integration of Situational Factors and Psychological Processes in Immoral Behavior, 6 REV. GENDER PSYCHOL. 25, 25, 34 (2002) (presenting "a model of evil behavior demonstrating how situational factors that obscure moral relevance can interact with moral rationalization and lead to a violation of moral principles").

13 Bandura, Impeding Ecological Sustainability, supra note 9, at 24 (examining the selective disengagement of moral self-sanctions as an impediment to reversing ecological degradation); see also Albert Bandura, Failures in Self-Regulation: Energy Depletion or Selective Disengagement?, 7 PSYCHOL. INQUIRY 20 (1996) [hereinafter Bandura, Failures in SelfRegulation]; Bandura, Moral Disengagement in the Perpetration of Inhumanities, supra note 8; Bandura, Social Cognitive Theory of Self-Regulation, supra note 10; Bandura et al., supra note 8; Michael J. Osofsky et al., The Role of Moral Disengagement in the Execution Process, 29 LAW \& HUMAN BEHAV. 371, 372 (2005).

14 Bandura, Impeding Ecological Sustainability, supra note 9, at 10; see also Bandura, Failures in Self-Regulation, supra note 13; Bandura, Moral Disengagement in the Perpetration of Inhumanities, supra note 8; Bandura, Social Cognitive Theory of Self-Regulation, supra note 10; Bandura et al., supra note 8, at 367 (showing positive relationship between moral disengagement and aggression); Alfred L. McAlister et al., Mechanisms of Moral Disengagement in Support of Military Force: The Impact of Sept. 11, 25 J. Soc. \& CliniCAL PSYCHOL. 141, 142 (2006); Osofsky et al., supra note 13 .

15 Bandura, Impeding Ecological Sustainability, supra note 9, at 11.

16 See Bandura et al., supra note 8 (showing the positive relationship between moral disengagement and aggression).

17 Bandura, Moral Disengagement in the Perpetration of Inhumanities, supra note 8; see also Bandura, Selective Activation and Disengagement of Moral Control, 46 J. OF SOCIAL ISSUES 27 (1990) [hereinafter Bandura, Selective Activation and Disengagement of Moral Control]. Gradual escalation of harmful behavior was most notably demonstrated in Philip Zimbardo's famous Stanford prison experiment. See David Crump, The Social Psychology of Evil: Can the Law 
of reprehensibility [of the individual's conduct] progressively increases." 18 Through this process, an individual will initially "perform questionable acts that [she] can tolerate with little self-censure," and repeat performances of the same act will produce less "discomfort and self-reproof" after each performance. ${ }^{19}$

Prevent Groups from Making Good People Go Bad?, 2008 BYU L. REV. 1441, 1445-46 (2008). In his study, Zimbardo recreated a prison environment in the basement of a Stanford University building wherein he recruited randomly chosen male college students to participate in the study, randomly assigned them to act as either prisoners or guards, and gave them great latitude in determining how to behave. See id. at 1446; PhILIP G. ZiMBARDO, ThE LuCIFER EFFECT: Understanding How GoOd PEOPLE TURN Evil 23-94 (2007). The students assigned to the role of prison guards conformed their attitudes to fit their punitive roles and "imposed increasingly degrading punishments upon "prisoners[,]"” so much so that Zimbardo was forced to end the experiment prematurely. See Philip G. Zimbardo et al., Reflections on the Stanford Prison Experiment: Genesis, Transformations, Consequences, in OBEDIENCE TO AUTHORITY: Current Perspectives ON the Milgram PARAdigm 193 (Thomas Blass ed., 2000); see also Craig Haney et al., A Study of Prisoners and Guards in a Simulated Prison, NAVAL RES. REV. (1973).

18 Bandura, Selective Activation and Disengagement of Moral Control, supra note 17, at 42. The phenomenon of escalating misconduct can be explained through Festinger's related theory of cognitive dissonance. According to cognitive dissonance theory, mental tension is created when one engages in behavior conflicts with her beliefs. See, e.g., Crump, supra note 17, at 1444-45; see also Daryl J. Bem, Self-Perception: An Alternative Interpretation of Cognitive Dissonance Phenomena, 74 PSYCHOL. REV. 183, 187 (1967). In order to reduce the tension caused by the dissonance, individuals will modify their beliefs, aligning their beliefs with their behavior. See $i d$. Belief modification that is motivated by dissonance reduction not only changes the way current behavior is perceived, but often results in permanent changes in future behavior. See Jeff Stone \& Nicholas C. Fernandez, How Behavior Shapes Attitudes: Cognitive Dissonance Processes, in Attitudes AND Attitude Change 313, 316 (William D. Crano \& Radmila Prislin eds., 2008) ("The psychological processes by which people restore consistency among cognitions can lead to enduring and meaningful changes ....").

19 Bandura, Selective Activation and Disengagement of Moral Control, supra note 17, at 42. Studies on "desensitization," which have demonstrated that the more one is exposed to depictions of violence, the less one will become emotionally aroused by it, shed further light on the phenomenon of escalation of wrongdoing. See, e.g., Bruce D. Barthalow et al., Chronic Video Game Exposure and Desensitization to Violence: Behavioral and Event-Related Brain Potential Data, 42 J. EXPERIMENTAL SOC. PSYCHOL. 532, 537 (2006) (finding that exposure to violence can result in violence desensitization, which places individuals at an increased risk of future violent conduct); Nicholas L. Carnagey et al., The Effect of Video Game Violence on Physiological Desensitization to Real-Life Violence, 43 J. EXPERIMENTAL SOC. PSYCHOL. 489, 490 (2007). According to Stelios Zyglidopoulos, the escalation of corrupt conduct takes place because people tend to overcompensate when rationalizing their behavior. See Stelios C. Zyglidopoulos et al., Rationalization, Overcompensation and the Escalation of Corruption in Organizations, 84 J. BUS. ETHICS 65 (2009). Using the case of the 2001 Enron corruption as an example, the authors observed that the Enron executives used rationalizations that were out of proportion to the initial fraud. The executives used grandiose statements such as "we do this because we are saving this great firm," which evolved into "we do this because we are saving our great economy," to justify their behavior. Id. at 5. Zyglidopoulos explained that these explanations, despite their apparent pompous assertions, are not irrational; rather, they are the natural consequence of uncertainty. Id. They explained that people are likely to take a "better safe than sorry" approach, providing rationalizations that are greater than necessary to justify the act. Id. As the authors explained, however, "[w] hen the rationalization is bigger than the initial corrupt act, the way is paved for further and more extensive corruption since such acts already have ... an ideological cover." Id. at 6 . The rationalization allows the actor to engage in further corrupt acts that surpass the scope of original rationalization. Id. To justify these further acts the 
An individual's level of moral disengagement from self-sanctions for engaging in particular conduct can be affected by the role the individual plays within the particular social structure. ${ }^{20}$ Even those who begin as idealistic may become morally disengaged over time when operating within an environment with social constructs that foster moral disengagement. For example, Osofsky, Bandura, and Zimbardo recently examined randomly selected prison personnel and found that members of execution teams who were not self-selected but rather were assigned to such duty showed higher levels of moral disengagement than those less involved or not involved in the execution process. ${ }^{21}$ Osofsky's study also found that members of the prison's emotional support teams generally began their employment with high levels of moral engagement, yet became increasingly morally disengaged as involvement in the execution process increased. ${ }^{22}$

actor is forced to provide yet another rationalization, which will again overcompensate for the wrong. Id.

20 See, e.g., Osofsky et al., supra note 13, at 388 (finding "gradual transformation of members of the [psychological] support team from being moral engagers to moral disengagers with increasing participation in executions"); see also Celia Moore, Moral Disengagement in Processes of Organizational Corruption, 80 J. Bus. ETHICS 129, 131 (2008) (examining how "mechanisms of moral disengagement help to initiate, facilitate, and perpetuate corruption in organizations"). Legal scholars have applied moral disengagement theory on a social systems level to identify conditions structured into the criminal justice system that encourage moral disengagement in capital juries. See Craig Haney, Violence and the Capital Jury: Mechanisms of Moral Disengagement and the Impulse to Condemn to Death, 49 STAN. L. REV. 1447, 1447 (1997); see also H. Mitchell Caldwell \& Thomas W. Brewer, Death Without Due Consideration?: Overcoming Barriers to Mitigation Evidence By "Warming" Capital Jurors to the Accused, 51 How. L.J. 193, 247 (2008). Such disengagement has also been studied in the context of mental heath professionals who are involved in capital cases. See Donald P. Judges, The Role of Mental Health Professionals in Capital Punishment: An Exercise in Moral Disengagement, 41 Hous. L. REV. 515 (2004).

21 See Osofsky et al., supra note 13, at 382 .

22 Id. at 384-85; see also Albert Bandura, The Evolution of Social Cognitive Theory, in Great Minds in Management: The Process of Theory Development 9, 22 (Ken G. Smith \& Michael A. Hitt eds., 2005) (examining the "form that moral disengagement takes and the justificatory exonerations and social arrangements that facilitate their use in different detrimental corporate practices"); see also Albert Bandura et al., Corporate Transgressions, in ETHICS IN THE ECONOMY: HANDBOOK OF BUSINESS ETHICS 151, 151, 162 (László Zsolnai ed., 2002) (discussing the process by which corporate managers selectively disengage moral self-sanctions from their transgressive conduct); Albert Bandura, Selective Exercise of Moral Agency, in NuRTURING MORALITY 37 (Theresa A. Thorkildsen \& Herbert J. Walberg eds., 2004); Bandura, Moral Disengagement in the Perpetration of Inhumanities, supra note 8; Jenny White et al., Moral Disengagement in the Corporate World, 16 ACCOUNTABILITY IN RES. (2009). 


\section{Mechanisms Disengaging Prosecutors' SELF-SANCTIONS FOR MISCONDUCT}

\section{A. The Ethical Prosecutor and the Competing Motivation to Win}

Prosecutors wield enormous power. They possess almost unfettered discretion in certain key decisions, such as who to charge for what crime, whether to seek the death penalty, and whether to permit a plea. ${ }^{23}$ They often possess greater resources than their defense attorney counterparts, ${ }^{24}$ and because they "represent[] the community, [they] commonly carr[y] more influence with juries than attorneys allied solely with individual clients." 25 Given this power and discretion, prosecutors occupy a special position of trust as "minister[s] of justice," 26 a responsibility that "carries with it specific obligations to see that the defendant is accorded procedural justice and that guilt is decided upon the basis of sufficient evidence." 27 As the Supreme Court explained in an oft-cited quote:

The [prosecutor] is the representative not of an ordinary party to a controversy, but of a sovereignty whose obligation to govern impartially is as compelling as its obligation to govern at all; and whose interest, therefore, in a criminal prosecution is not that it shall win a case, but that justice shall be done. As such, he is in a peculiar and very definite sense the servant of the law, the twofold aim of which is that guilt shall not escape or innocence suffer. He may prosecute with earnestness and vigor-indeed, he should do so. But, while he may strike hard blows, he is not at liberty to strike foul ones. It is as much his duty to refrain from improper methods calculated to produce a wrongful conviction as it is to use every legitimate means to bring about a just one. ${ }^{28}$

The "doing justice" standard could be subject to many interpretations, and some prosecutors may believe that they are "doing

23 As both Paul Butler and Angela Davis both point out, line prosecutors possess less discretion than their elected or appointed supervisor. See PAUL BUTLER, LET'S GET FREE: A HIPHOP THEORY OF JUSTICE 118 (2009); DAVIS, supra note 1.

24 David Luban, Lawyers \& Justice: An Ethical Study 79 (explaining that in the United States, for indigent cases, defense attorneys often receive less than half the financial resources that are available to the prosecution, and arguing that the disparity between prosecutor and defense resources prevents the presumed equal advocacy by the opposing sides); see also The Spangenberg Group, The Tennessee Justice Project's Summary Analysis of: Resources of the Prosecution And Indigent DefEnse Functions in TenNessee (2007), http://www.thejusticeproject.org/wp-content/uploads/spangenberg-summary-analysis.pdf.

25 Fred C. Zacharias, Structuring the Ethics of Prosecutorial Trial Practice: Can Prosecutors Do Justice?, 44 VAND. L. REV. 45, 59 (1991).

26 MOdel RUles of PROF'L CONDUCT R. 3.8 cmt. (2000).

$27 \mathrm{Id}$.

28 Berger v. United States, 295 U.S. 78, 88 (1935). 
justice" when they keep defendants they believe to be guilty off the street, even if they need to engage in procedural misconduct to ensure convictions. However, prosecutors who believe that they are serving a higher good when they engage in prosecutorial misconduct have an internal ethical code that is out of sync with the prosecutors' ethical obligations. Furthermore, prosecutors take an oath of office swearing to uphold the law, and every prosecutor is expected to conform her personal ethical code to the baseline ethical code that is established by law. I believe most prosecutors join the profession intending to prosecute honestly, fairly, and in accordance with the ethical rules applicable to the office. Therefore, the focus of this Article is: Can these "ethical people" remain ethical as prosecutors? More specifically, does the current prosecutorial system encourage these "ethical people" to remain ethical as prosecutors, and if not, how can it be reformed?

Some legal scholars who have considered whether a "good person" can be a good prosecutor have answered the question with skepticism. Abbe Smith believes that well-intentioned prosecutors, whom she defines as those who are "conscientious, prudent, and sociallyconscious," 29 are too often corrupted by public and institutional pressure to win, as well as by a tendency toward self-importance and cynicism that is bred by the prosecutors' role and institutional culture. She concludes that " $[t]$ he desire to win inevitably wins out over matters of procedural fairness, such as disclosure." 30

While I do not believe that all prosecutors succumb to the desire to win at the expense of their ethical standards, extensive scholarly work has focused on the pressures that induce some prosecutors to engender what has been called a "conviction psychology," 31 which is the desire to seek convictions, "even when doing so may subvert justice."32 Such work has focused primarily on the institutional pressures that lead to the conviction mentality. Prosecutors' careers are directly hampered or

29 Abbe Smith, Can You Be a Good Person and a Good Prosecutor?, 14 GeO. J. LEGAL ETHICS 355, 374-75 (2001). Paul Butler considers a similar question in his recent book, where he considers whether a "good person" who he describes as one who is "concerned with economic and racial justice" and wants to "help resolve unfairness in the criminal justice system," should be a prosecutor. See BUTLER, supra note 23, at 101-02. While stopping short of arguing that wellintentioned prosecutors are corrupted to the point of prosecutorial misconduct, Professor Butler concludes that good people often "get derailed for three reasons: the adversarial system, law-andorder culture, and the politics of crime." Id. at 114.

30 Smith, supra note 29, at 390.

31 See, e.g., George T. Felkenes, The Prosecutor: A Look at Reality, 7 Sw. U. L. REV. 98, 110 (1975) ("The prosecutor who displays 'conviction psychology' thinks of the defendant as guilty, and reasons that an innocent person would not be introduced into the system. He sees the judicial system as the means through which he must work in order that the guilty might receive their proper punishment.... The result of these attitudes is a deterioration of the ideal purpose of the prosecutor - to seek justice.”).

32 Keith A. Findley \& Michael S. Scott, The Multiple Dimensions of Tunnel Vision in Criminal Cases, 2006 WIS. L. REV. 291, 328. 
enhanced by their conviction rates. In most jurisdictions, the prosecutors who obtain "the highest conviction rates (and, thus, reputations as the best performers) stand the greatest chance for advancement internally." 33 Prosecutors' offices keep track of individual prosecutors' conviction rates as a "motivational device-for example, by internally distributing attorneys' 'batting averages,' or listing each lawyer by name on a bulletin board with a series of stickers reflecting the conclusions of their recent cases (green for convictions and red for acquittals)." 34 Prosecutors' offices also use conviction records to justify their budgets. ${ }^{35}$

Contributing to the institutional pressure to convict is the public pressure to convict. As Findley and Scott have discussed, while the public views the police force as having a broader mandate, the public sees the role of the prosecutor as limited to prosecuting offenders. ${ }^{36}$ It is understandable, then, that prosecutors rely on their conviction rates as evidence that they are capable and tough on crime in both their campaigns for re-election as well as in their future political campaigns. ${ }^{37}$

This focus on conviction rate can be self-reinforcing. As Daniel Medwed has discussed, "[a]s members of organizations that hail convictions... prosecutors may begin to internalize the emphasis placed on conviction rates and view their win-loss record as a symbol of their self-worth."38 Professor Paul Butler recently described his own experience as a former prosecutor, explaining:

My aspirations of changing the system got shot down because I liked winning too much, and I was good at it. I wanted to be well regarded by my peers, to be successful in my career, and to serve my community. And the way to do that, I learned on the job, was to send as many people to jail as I could. I wasn't so much hoodwinked as seduced. ${ }^{39}$

33 Daniel S. Medwed, The Zeal Deal: Prosecutorial Resistance to Post-Conviction Claims of Innocence, 84 B.U. L. REV. 125, 134-35 (2004); see also Bandes, supra note 7, at 484 . Others have suggested, however, that it is not the rate of conviction that is correlated with career advancement, but rather the length of the resulting prison sentence. See, e.g., Richard T. Boylan, What Do Prosecutors Maximize? Evidence from Careers of U.S. Attorneys, 7 AM. L. \& ECON. REV. 379, 396 (2005).

34 Daniel S. Medwed, The Prosecutor as Minister of Justice: Preaching to the Unconverted From the Post-Conviction Pulpit, 84 WASH. L. REV. 35, 44 (2009).

35 Id. at 45.

36 Findley \& Scott, supra note 32, at 327.

37 See, e.g., Stephanos Bibas, Plea Bargaining Outside the Shadow of Trial, 117 HARV. L. REV. 2463, 2472 (2004) (discussing prosecutors' use of conviction rates in their campaigns for re-election as district attorneys, as well as future campaigns for higher political office); see also Medwed, supra note 33, at 151-56 (discussing prosecutors' focus on conviction rates in reelection campaigns as well as in campaigns for higher office).

38 Medwed, supra note 33, at 138.

39 BUTLER, supra note 23, at 105. 
Empirical data confirms that "the more experience a prosecutor has, the more likely he or she is to express an interest in obtaining convictions over an interest in doing justice." 40

In light of such strong motivation to convict, the prosecutorial system should provide adequate support for the ethical prosecutors' countervailing desire to adhere to her internal code of ethics. However, an analysis of the prosecutorial system demonstrates that mechanisms exist in the prosecutorial structure that encourage moral disengagement in prosecutors. Specifically, the prosecutorial system encourages moral disengagement in prosecutors by providing a vague, but powerful, moral justification for potential wrongdoing, by obscuring prosecutors' personal agency, and by depersonalizing defendants.

\section{B. Moral Justification}

The first set of disengagement mechanisms serves to "transform harmful practices into worthy ones through social and moral justification ...." 41 The prosecutor's duty to see that "justice shall be done" 42 provides a strong moral justification for the prosecutor's actions as a zealous advocate on behalf of "the people," including victims, police, and the public. This moral justification necessarily provides an exonerative umbrella for the prosecutor's actions, as some disengagement from self-sanctions is necessary for a prosecutor to fulfill her role. While a person's moral self-sanctions may otherwise be activated if she deprived another person of her liberty or life, the prosecutor's self-sanctions must be disengaged from this otherwise inhibited conduct in order for her to function within her role as prosecutor.

While a sense of having the moral high-ground may provide some needed exoneration from engaging in otherwise harmful behavior, a sense of moral superiority can be dangerous without specific guidance. A recent social science study of students and cheating found that the "worst" cheaters were students who demonstrated a strong sense of moral superiority and considered cheating ethically justifiable. ${ }^{43}$ The study's authors determined that those who considered themselves most moral believed their classroom cheating was justified because they

40 Findley \& Scott, supra note 32, at 329, (discussing George T. Felkenes's study, which reported survey data of district attorneys).

41 Bandura, Impeding Ecological Sustainability, supra note 9, at 10 (examining the selective disengagement of moral self-sanctions as an impediment to reversing ecological degradation).

42 Berger v. United States, 295 U.S. 78, 88 (1935).

43 See Scott J. Reynolds \& Tara L. Ceranic, The Effects of Moral Judgment and Moral Identity on Moral Behavior: An Empirical Examination of the Moral Individual, 92 J. APPLIED PSYCHOL. 1610, 1621-22 (2007). 
would contribute the most value to society if successful in school. ${ }^{44}$ To counter this sense of moral justification, the authors discussed the need for specific guidelines and training to ensure that those with high moral purpose do not pursue illegitimate means in order to accomplish their moral ends. ${ }^{45}$

Rather than providing specific guidance to prosecutors, the American Bar Association's Model Rules of Professional Conduct and the Supreme Court provide little explanation of what it means to be a minister of justice, ${ }^{46}$ and the ethical standards that do exist to guide prosecutors' conduct are not enforced. ${ }^{47}$ Prosecutors "rarely receive ethical sanctions for their misconduct, even when it leads to wrongful conviction."48 In fact, "an investigation by the Center for Public Integrity revealed only forty-four cases (between 1970 and 2003) in

44 See Jeanna Bryner, Oddly, Hypocrisy Rooted in High Morals, LIVESCIENCE, Nov. 14, 2007, http://www.livescience.com/strangenews/071114-cheating-basics.html (featuring an interview with Reynolds discussing the study).

$45 \mathrm{Id}$.

46 See Zacharias, supra note 25, at 46.

47 While various professional associations like the American Bar Association and the National District Attorneys Association, have promulgated more specific ethical guidelines for prosecutors, such standards are merely aspirational, and prosecutors need not adhere to them or even consider them. For a discussion of such standards, see DAVIS, supra note 1, at 15-16, 14849.

48 Jane Campbell Moriarty, "Misconvictions," Science, and the Ministers of Justice, 86 NEB. L. REV. 1, 29 (2007). One striking example of the lack of consequences for prosecutors comes from California, where the judges are required to report prosecutorial misconduct to the attorney disciplinary board, in the event that the judge reverses a conviction based upon such wrongdoing. The California Commission on the Fair Administration of Justice, in conjunction with Professor Cookie Ridolfi of Santa Clara University School of Law, studied 2130 California cases over a ten-year period ending in 2006, in which claims of prosecutorial misconduct were raised. In 443 of the cases, the court had concluded that prosecutorial misconduct did occur. In 390 of these cases, the court concluded the misconduct was harmless error and affirmed the conviction. In fifty-three cases, the misconduct resulted in a reversal of the conviction. However, in none of the cases did the judge report the prosecutor to the disciplinary committee. See CAL. COMM'N ON THE FAIR ADMIN. OF JUSTICE, REPORT AND RECOMMENDATIONS ON REPORTING MisCONDUCT (FORMERLY TITLED PROFESSIONAL MISCONDUCT AND ACCOUNTABILITY OF PROSECUTORS AND DEFENSE LAWYERS) (2007), http://www.ccfaj.org/documents/reports/prosecutorial/official/ OFFICIAL\%20REPORT\%20ON\%20REPORTING\%20MISCONDUCT.pdf. In another startling example, Ken Armstrong and Maurice Possley studied eleven thousand cases involving prosecutorial misconduct between 1963 and 1999 and found widespread concealment of exculpatory evidence and presentation of false evidence. See Ken Armstrong \& Maurice Possley, The Verdict: Dishonor, CHI. TRIB., Jan. 10, 1999, at C1, available at http://www.chicagotribune.com/news/watchdog/chi-020103trial1,0,1561461,full.story. Yet, none of the prosecutors who engaged in the misconduct were convicted of a crime or barred from practicing law, and many of the prosecutors actually advanced significantly in their careers. See id.; see also DAVIS, supra note 1, at 135-36; Ellen Yaroshefsky, Wrongful Convictions: It Is Time to Take Prosecution Discipline Seriously, 8 UDC/DCSL L. REV. 275, 278-79 (2004) ("With rare exception, there has been no discipline for egregious instances of misconduct that led to these convictions."); BUTLER, supra note 23, at 118 (explaining that "[t]here are few risks to being overaggressive - even when prosecutors cross the line" and citing as support that "[s]ince 1976, approximately 120 people who received death sentences were later found to be innocent," and while the prosecutors were "responsible for these wrongful convictions," none were disciplined). 
which prosecutors faced disciplinary proceedings for misconduct." 49 Additionally, "the U.S. Supreme Court provides no remedy for prosecutorial misconduct in cases involving harmless error, and it provides prosecutors immunity from civil lawsuits." 50

By encouraging convictions while condoning the violation of ethics rules, ${ }^{51}$ the prosecutorial system sends the implicit message that prosecutors have a moral mandate to procure convictions at all costs. When an institution provides a moral justification for harmful behavior, an individual's "detrimental conduct is made personally and socially acceptable by portraying it as serving socially worthy or moral purposes." 52 This allows people to "act on a moral imperative and preserve their view of themselves as moral agents while inflicting harm on others." ${ }_{53}$ This not only reduces self-sanctions but also can even result in feelings of personal pride for actions that would otherwise be immoral. ${ }^{54}$ As Bandura noted, "[o]ver the centuries, much destructive conduct has been perpetrated by ordinary, decent people in the name of righteous ideologies, religious principles, and nationalistic imperatives." 55

\section{Obscuring Personal Agency}

The second set of disengagement mechanisms obscure the causal relationship between the individual's conduct and the outcomes of the

49 See DAVIS, supra note 1 , at 182.

50 The Supreme Court has held that prosecutors enjoy absolute immunity and cannot be sued even if acting intentionally, in bad faith, and with malice, when engaged in presenting their cases in court, Imbler v. Pachtman, 424 U.S. 409, 424-31 (1976), but enjoy only qualified immunity during the investigative stages. Burns v. Reed, 500 U.S. 478, 494-96 (1991). In 2009, the Supreme Court granted certiorari and heard oral arguments in Pottawattamie County v. McGhee, 130 S. Ct. 1047 (2009), to consider whether prosecutors should enjoy absolute or qualified immunity to civil suits for falsifying evidence during the investigative state that they later used in trial; however, the government settled with the plaintiffs before the Court issued an opinion in the case, necessitating dismissal. See David G. Savage, Prosecutor Conduct Case Before Supreme Court Is Settled, L.A. TIMES, Jan. 5, 2010, at A9, available at http://articles.latimes.com/2010/jan/05/nation/la-na-court-framed5-2010jan05.

51 Judge Emmet Sullivan, who dismissed the indictment against former Alaskan Senator Ted Stevens, recently appointed an attorney to investigate and potentially prosecute the public integrity prosecutors who engaged in prosecutorial misconduct for obstruction of justice and violating court orders. See Neil A. Lewis, Tables Turned on Prosecution in Stevens Case, N.Y. TIMES, Apr. 7, 2009. While criminal prosecution for prosecutorial misconduct is therefore theoretically possible, it is far from the prevailing norm.

52 Bandura, Moral Disengagement in the Perpetration of Inhumanities, supra note 8, at 194.

$53 \mathrm{Id}$.

54 See White et al., supra note 22, at 47. See generally McAlister et al., supra note 14 (evaluating the public acceptance of the use of military force against terrorists, both before and after the terrorist attacks on New York City's Twin Towers, using the lens of moral disengagement).

55 Bandura, Moral Disengagement in the Perpetration of Inhumanities, supra note 8, at 195. 
behavior. Through these mechanisms, "people are absolved of a sense of personal accountability for harmful practices by displacement and diffusion of responsibility." 56

\section{Displaced Responsibility}

When responsibility is displaced, individuals are able to pardon their conduct by perceiving their actions as being ordered by others. ${ }^{57}$ Perhaps the most famous study demonstrating displacement of responsibility is that conducted by Stanley Milgram. ${ }^{58}$ In Milgram's seminal study, an authoritative experimenter instructed subjects to administer increasingly intense shocks to "learners," confederates who provided incorrect answers, as a test of the effects of punishment on learning. Milgram found that of forty subjects, twenty-six were willing to comply with the experimenter's command to progress to a dangerously high voltage level.

While prosecutorial misconduct is not directly authorized, as was the conduct in the Milgram experiment, the prosecutorial system may actually encourage prosecutors to "convict at all costs" through what Bandura refers to as "[i]mplicit agreements, insulating social arrangements and authorization by indirection." 59 Through intense pressure to convict at all costs, and lack of sanctions for violation of ethical rules, such misconduct is implicitly authorized. As Bandes has explained, "the prosecutor works within a particular institutional environment, which will generate explicit procedures, but will also transmit implicit institutional expectations." 60

Such implicit authorization regimes, especially those that are infused with moral justification, can be especially dangerous, because obedient functionaries within implicit authorizing systems, in contrast to actors within direct authorizing systems, "do not cast off all responsibility as if they were mindless extensions of others. [Otherwise], they would perform their duties only when told to do so." 61 As Bandura explains, "[i]t requires a strong sense of responsibility, rooted in ideology, to be a good functionary. . . . The best functionaries are those who honor their obligations to authorities but feel no personal

56 Bandura, Impeding Ecological Sustainability, supra note 9, at 10-11.

57 See White et al., supra note 22, at 47.

58 Stanley Milgram, Behavioural Study of Obedience, in CONFLICT, ORDER \& ACTION: READINGS IN SOCIOLOGY 134 (Ed Ksenych \& David Liu eds., 3d ed. 2001) (explaining why and when people obey authority).

59 Bandura, Moral Disengagement in the Perpetration of Inhumanities, supra note 8, at 197.

60 See Bandes, supra note 7, at 484.

61 Bandura, Moral Disengagement in the Perpetration of Inhumanities, supra note 8, at 197. 
responsibility for the harm they cause. They work dutifully to be good at their [wrongdoing]." 62

\section{Diffusion of Responsibility}

Similar to displacement of responsibility, the "exercise of moral control is also weakened when personal agency is obscured by diffusing responsibility for detrimental behavior." 63 One's sense of responsibility can be diffused, and thereby diminished, by dividing an enterprise into detached subfunctions. ${ }^{64}$ In his seminal study on disinhibition of aggression through diffusion of responsibility and dehumanization of victims, Bandura found that subjects, when told that the level of shock a victim received would be based on an average shock administered by multiple subjects, were willing to administer a higher shock than those subjects who were told that they would be the sole determinant of the shock amplitude administered.65 Thus, diffusion of responsibility disinhibited subjects to engage in more injurious behavior. ${ }^{66}$

The criminal justice system diffuses the prosecutor's responsibility by dividing the truth finding function. As Bandes explains, the adversary system "is built on the notion that if each adversary acts zealously on behalf of his client, the truth will come out." 67 Because the adversary system parcels out "the search for justice" between "two adversaries acting zealously, with the judge or jury making the final determination," the prosecutor may "come to believe that the obligation to truth will be safeguarded by the system in general." 68 This freedom from the personal responsibility to safeguard the defendant's rights, although illusory, ${ }^{69}$ may disinhibit the prosecutor to pursue his case with increased zealousness and to pursue a conviction, even at the expense of compliance with ethical rules.

62 Id. at $197-98$.

63 Id. at 198.

64 See id.

65 Albert Bandura et al., Disinhibition of Aggression Through Diffusion of Responsibility and Dehumanization of Victims, 9 J. RES. IN PERSONALITY 253, 259 (1975) (demonstrating increased subject aggressiveness when subjects were told the magnitude of a shock was based on a group average and when the victim was referred to in terms of dehumanizing terminology).

$66 I d$. at 257.

67 Bandes, supra note 7, at 488.

68 Id. at 489; see also Haney, supra note 20, at 1476 (discussing the role of distal responsibility in allowing capital juries to condemn defendants to death, and reporting that jurors tend to focus on the judge's instructions indicating that the jury's decision is only a "recommendation").

69 In his seminal work Lawyers \& Justice: An Ethical Study, David Luban debunks the "checks-and-balances theory" of the "ethical division of labor" between public entities, explaining that "the adversary advocate attempts to evade the system of checks and balances, not to rely on it to save people from her." LUBAN, supra note 24 , at 79. 


\section{Depersonalizing Defendants}

Through the third set of disengagement mechanisms, which operate at the recipient locus, targets of harmful conduct are depersonalized ${ }^{70}$ and blamed for bringing about their own suffering. ${ }^{71}$ Through depersonalization, self-censure for harmful conduct "can be disengaged by stripping people of human qualities [such that] they are no longer viewed as persons with feelings, hopes and concerns, but as subhuman objects." 72 Social psychologists have described this "dehumanization" as one of the "most powerful cognitive processes that can distance people from the moral implications of their actions." 73

Defendants in the criminal justice system are systematically depersonalized from the prosecutor's perspective, because the prosecutor has intimate contact with all parties involved except the defendant. As Stanley Fisher has explained:

In her daily routine, [the prosecutor] is constantly exposed to victims, police officers, civilian witnesses, probation officers and others who can graphically establish that the defendant deserves punishment and who have no reason to be concerned with competing values of justice. At the same time, the prosecutor is normally isolated from those - the defendant, his family and friends, and often, his witnesses - who might arouse the prosecutor's empathy or stimulate concern for treating him fairly. ${ }^{74}$

In the vacuum of humanizing information about the defendant, the prosecutor formulates her theory of her case, which can be tainted by the "fundamental attribution error"- the tendency to "provid[e] causal explanations for the behavior of others in largely dispositional or personal as opposed to situational or contextual terms."75

The use of blanket terms in the place of individual names, such as "the defendant" or "the perp," as well as derogatory labels for defendants, such as "scum," further dehumanizes the defendant. Martha Duncan has argued that "metaphors of filth" permeate the criminal justice system, and in one study cited thirty-four appellate cases where prosecutors' references to defendants as "slime," "scum," "filth," or

70 See Bandura, Impeding Ecological Sustainability, supra note 9, at 11.

71 McAlister et al., supra note 14, at 142.

72 Bandura, Moral Disengagement in the Perpetration of Inhumanities, supra note 8, at 200; see also White et al., supra note 22, at 47.

73 Haney, supra note 20, at 1454; see also Bandura, supra note 65, at 259 (demonstrating increased subject aggressiveness when subjects where told the magnitude of a shock was based on a group average and when the victim was referred to in terms of dehumanizing terminology).

74 Stanley Z. Fisher, In Search of the Virtuous Prosecutor: A Conceptual Framework, 15 AM. J. CRIM. LAW 197, 208 (1988).

75 Haney, supra note 20, at 1459. 
"dirt" was at issue. ${ }^{76}$ As Craig Haney explains, the use of such "imagery cognitively reinforce[s] the separation of the 'criminals' from the "noncriminals' who employ[] the terminology."77 Professor Paul Butler recently described the depersonalization of defendants through reference to his own experience as a prosecutor:

I didn't start right in calling the defendants "cretins" and "douche bags." Obviously, however, criminal defendants are not highly regarded in prosecutor offices. In many cases, this is with good reason; some defendants are stupid, some have done vile things, and others have comically bad luck. In your day-to-day work as a prosecutor, defendant sob stories about growing up in foster care, getting beat up by the police, or not being able to afford rehab are obstacles to your success. ${ }^{78}$

The institutional power dynamic between prosecutors and defendants further compounds the dehumanizing effect. "[W]ielding institutional power changes the power holders in ways that are conducive to dehumanization." 79 As Bandura explains, "[t]his happens when persons in positions of authority have coercive power over others with few safeguards to constrain their behavior. Power holders come to devalue those over whom they wield control." 80 Prosecutors have enormous power over defendants, including the power to determine whether to bring charges and what charges to file, to engage in plea discussions, and to dismiss charges. ${ }^{81}$ In fact, as Paul Butler explains, the lead prosecutor in the jurisdiction "often has more control than the judge over the outcome of the case," because she has unfettered discretion to decide whether to prosecute a case, and she "can circumvent required sentences simply by charging a different crime, or leaving out some of the evidence." 82

The adversarial process can further lead to degradation of defendants, because prosecutors can easily attribute blame for their misconduct to the defense's provocation. As Bandura explains, "[c]onflictful transactions typically involve reciprocally escalative acts." 83 Thus, an actor in such an adversarial process may "select from the chain of events a defensive act by the adversary and portray it as initiating provocation." 84 Through this self-exoneration process, "not

76 Martha Grace Duncan, In Slime and Darkness: The Metaphor of Filth in Criminal Justice, 68 TUL. L. REV. 725 (1994).

77 Haney, supra note 20, at 1462.

78 BUTLER, supra note 23, at 116.

79 Bandura, Moral Disengagement in the Perpetration of Inhumanities, supra note 8, at 200.

$80 \mathrm{Id}$.

81 For a discussion of the powers of the prosecutor, see generally DAVIS, supra note 1, and BUTLER, supra note 23.

82 BUTLER, supra note 23, at 107.

83 Bandura, Moral Disengagement in the Perpetration of Inhumanities, supra note 8, at 203.

84 Id. 
only are one's own injurious actions excusable but one even can feel self-righteous in the process." 85 Through depersonalization of defendants, the wielding of power over defendants, and the adversarial posture toward defendants, prosecutors are encouraged to morally disengage from harmful acts toward defendants.

\section{SYSTEMIC REFORMS}

Because moral disengagement may lead to prosecutorial misconduct, reforms aimed at minimizing prosecutorial misconduct will be most effective if they take into account the forces of moral disengagement at work in the criminal justice system and provide systemic correctives to mitigate such disengagement. This Article does not attempt to consider all of the reforms to the criminal justice system which may reduce prosecutorial misconduct. Rather, this Article considers two categories of proposed reforms, community prosecution and audits, that may reduce prosecutorial misconduct, in part, through the reduction of moral disengagement in prosecutors. ${ }^{86}$

\section{A. Community Prosecution}

Beginning in the 1990s, a handful of prosecutors' offices began engaging in practices that would later be defined as "community prosecution." 87 Since that time, the community prosecution movement has gained momentum among state prosecutors, so much so that a survey by the American Prosecutors Research Institute (APRI) conducted in 2003 found that "nearly half of all prosecutors' offices engage in some activity defined as community prosecution." 88 Community prosecutors take a more holistic approach to public safety and define their mission to include "improv[ing] public safety and enhanc[ing] the quality of life in the community." 89 Two of the key

85 Id.; see also Bandura et al., supra note 65, at 258-59 (demonstrating increased subject aggressiveness when subjects where told the magnitude of a shock was based on a group average and when the victim was referred to as "animalistic" and "rotten" rather than "perceptive" and "understanding"); White et al., supra note 22, at 52-56 (noting that corporations frequently blame and attribute negative qualities to the users of their harmful products).

86 Law schools may also play a role in encouraging moral disengagement through the casediscourse method. This subject is addressed in a forthcoming article by this author.

87 See NAT'L Dist. ATt'ys ASs'N \& NAT'L CTR. FOR CMTY. Prosecution, Key PRINCIPLES OF COMMUNITY PROSECUTION (2009) [hereinafter KEY PRINCIPLES OF COMMUNITY PROSECUTION], available at http://www.ndaa.org/pdf/final_key_principles_ updated_jan_2009.pdf.

$88 I \vec{d}$. at $\overline{2}$.

$89 \mathrm{Id}$. 
practices in community prosecution are seeking community-based solutions to public safety issues and evaluating outcomes through measurements beyond conviction rates. ${ }^{90}$

First, community prosecutors seek community-based solutions to public safety through open communication with community stakeholders and through partnerships with other agencies. In some jurisdictions, prosecutors are assigned to neighborhoods to focus on local crime and safety issues, and they maintain an open line of communication with community stakeholders by attending community meetings. Many community prosecutors consider non-violent offenders, particularly juveniles or those involving drug addiction, for diversion programs - such as drug treatment programs - as an alternative to prosecution or incarceration. Second, community prosecutors define a successful outcome, in other words, "doing justice," more expansively than through conviction rates alone. Some such offices consider a reduction in crime, or the number of calls from a particular neighborhood, to be a successful outcome. ${ }^{91}$ Similarly, a decline in the recidivism rate could be considered as a measure of success.

Each of these community prosecution practices can reduce prosecutorial misconduct through the reduction of moral disengagement. At the outset, decoupling job performance from conviction rate will reduce prosecutors' incentives to engage in moral disengagement in the first instance. Yet, community prosecution serves to reduce moral disengagement in further identifiable ways. First, community prosecution provides more specific guidance to the prosecutors' moral purpose. As Reynolds and Ceranic found in their study on those who feel a sense of moral superiority, the contours of the moral mandate they are given should be clearly identified and specific training should be provided. Therefore, where the pursuit of justice is defined as improving public safety and enhancing the quality of life in the community, and appropriate training is provided, those with a true calling to serve their moral purpose can be free to adhere to their internal ethical compass, rather than experiencing pressure to deviate from those ethics in order to succeed.

Second, considering defendants for diversion programs serves a personalization function by shifting the prosecutor's focus from the crime to the individual defendant. Prosecutors should be required to consider each non-violent offender, particularly juvenile defendants or those who are suffering from drug-addiction, for a diversion program. In an effort to increase the salience of the individual mitigating

90 See id. at 4; see also Voices from the Field: An Inter-Professional Approach to Managing Critical Information, 31 CARDOZO L. REV. 2037, 2074 (2010) (presentation by John Chisholm).

91 See Key Principles of COMMUnity ProseCution, supra note 87, at 4. 
circumstances and decrease the tendency to become entrenched in her opinion, the prosecutor could be required to include a statement in the file regarding the mitigating circumstances considered by the prosecutor when considering the defendant for the diversion program.

\section{B. Prosecutorial Review Boards}

Prosecutorial Review Boards have been proposed to address the accountability problem, but the reform has yet to be broadly adopted. As discussed above, due in part to the harmless error standard, and in part to lack of reporting, in general, a prosecutor suffers no adverse consequences after the finding of prosecutorial misconduct. A few District Attorneys, such as Charles "Joe" Hynes of Kings County, New York have instituted similar ethics oversight panels within their offices. ${ }^{92}$ In Kings County, the ethics officer reads the opinions issued in cases where prosecutorial misconduct was claimed, even if the conviction was affirmed. After investigating the facts, the ethics officer may refer an offending prosecutor to the bar committee, or may meet with the prosecutor to counsel her on how best to proceed in the future. ${ }^{93}$

While this system is a laudable first step, it focuses on a very small sample of cases, because ninety-five percent of criminal defendants plea rather than go to trial, and of those that do go to trial, many do not raise prosecutorial misconduct on appeal. Angela Davis has proposed a broader remedy to address the accountability problem. She proposes that "Prosecution Review Boards" be established by the organized bar not only to review complaints, but also to conduct random reviews of prosecution decisions, including charging and plea decisions. ${ }^{94}$ Under Professor Davis's model, board members would be "permitted to interview prosecutors, victims, and witnesses to determine if the prosecutors met the established standards" and would "file a public report upon completion of the review." 95 Such review boards would be established in conjunction with public information campaigns to inform the public regarding prosecutorial duties and responsibilities. ${ }^{96}$ Such a system would reduce moral disengagement in prosecutors, because it would remove the implicit authorization to engage in prosecutorial misconduct. Further, such a review system would increase prosecutors'

92 Hon. Charles J. Hynes, Dist. Att'y, Kings County, New York, Presentation at the Cardozo Law Review Symposium: New Perspectives on Brady and Other Disclosure Obligations: What Really Works? (Nov. 15, 2009) (transcript on file with the Cardozo Law Review).

93 Id.

94 DAVIS, supra note 1, at 184-85.

95 Id. at 185.

96 See id. 
awareness of their personal agency in procedural justice, thereby mitigating the division of the justice function among prosecutors, juries, and appellate courts. Once such review boards are established, compliance with ethical standards could serve as an identifiable measure upon which individual and office performance could be based. Such statistics could be explained in public information campaigns in an effort to increase reliance upon such statistics in prosecutorial elections.

\section{CONCLUSION}

Prosecutors generally join the profession because they want to serve their community. Moral disengagement theory provides a useful lens to analyze the process by which an ethical prosecutor may be encouraged to engage in prosecutorial misconduct. Through an ambiguous moral mandate to "do justice," the obscuration of personal agency, and the depersonalization of defendants, the prosecutorial system fosters misconduct by encouraging moral disengagement in prosecutors. Reforms such as the adoption of a community prosecution model and the establishment of prosecution review boards would support the internal moralist in each prosecutor, rather than encourage her to disengage her morality. While legislatures, the Supreme Court, and law schools each should also have a role in the reform effort, these reforms can and should be implemented by the self-regulating bar. 